\title{
PENINGKATAN KEMAMPUAN GURU SMP NEGERI 8 KOTA TEBING TINGGI DALAM MENYUSUN RENCANA PELAKSANAAN PEMBELAJARAN (RPP) KURIKULUM 2013 MELALUI KEGIATAN PENDAMPINGAN
}

\author{
Raimunda Simanjuntak
}

Surel: raimundasimanjuntak153@gmail.com

\begin{abstract}
ABSTRAK
Penelitian ini bertujuan untuk meningkatkan kemampuan guru-guru kelas VII SMP Negeri 8 kota Tebingtinggi dalam menyusun RPP menggunakan kurikulum 2013. Subjek penelitian ini adalah guru-guru kelas VII sebanyak 30 orang guru. Penelitian ini menggunakan pendekatan kualitatif. Jenis penelitian adalah penelitian tindakan kelas dengan menggunakan model Suharsimi Arikunto. Hasil penelitian ini menunjukkan bahwa kemampuan guru-guru kelas VII meningkat dalam merancang RPP menggunakan kurikulum 2013 setelah dilaksanakan kegiatan pendampingan. Hal ini dapat terlihat dari hasil penilaian dan observasi yang dilakukan oleh peneliti jika sebelum pendampingan dilakukan jumlah guru yang mampu membuat RPP dengan menggunakan kurikulu 2013 hanya sebanyak 6 orang guru (21\%) maka setelah siklus II dilaksanakan jumlah guru yang mampu membuat RPP kurikulum 2013 meningkat menjadi 26 orang guru (87\%). Terjadi peningkatan kemampuan guru sebanyak 20 orang (66\%).
\end{abstract}

Kata kunci : RPP, Kurikulum 2013, Pendampingan

\section{PENDAHULUAN}

Pendidikan merupakan proses interaksi dalam upaya mentransper informasi dan pembentukan karakter serta sikap yang sangat penting dalam upaya mengembangan sumber daya manusia Indonesia yang merupakan kebutuhan dasar bagi masyarakat yang ingin maju. Bagian penting pendidikan yang sangat berpengaruh untuk mendukung dan mensukseskan proses belajar mengajar ada 2 yaitu guru dan sarana serta prasarana.

"Proses peningkatan serta pengembangan kinerja dari seorang guru terbentuk dan terjadi dalam kegiatan belajar mengajar di tempat mereka bekerja. Kinerja seorang guru juga sangat dipengaruhi oleh hasil pembinaan dan supervisi kepala sekolah" (Pidarta, 1992:3). Seorang kepala sekolah memiliki peranan yang sangat penting dalam upaya membantu guru untuk meningkatkan kompetensi guru dalam merancang dan melaksanakan proses pembelajaran di dalam kelas. Kurikulum 2013 menuntut kemampuan baru pada guru untuk dapat mengelola proses pembelajaran secara efektif dan efisien. Tingkat produktivitas sekolah dalam memberikan pelayanan-pelayanan secara efisien kepada pengguna (peserta didik, masyarakat) akan sangat tergantung pada kualitas gurunya yang terlibat langsung dalam proses pembelajaran dan keefektifan mereka dalam melaksanakan tanggung jawab individual dan kelompok.

Rencana Pelaksanaan

Pembelajaran (RPP) yang sekarang 

dikembangkan menggunakan kurikulum 2013. RPP kurikulum 2013 berbeda dengan KTSP yang sebelumnya dipergunakan dikembangkan dan dirancang oleh guru pada satuan pendidikan. Guru pada satuan pendidikan berkewajiban menyusun RPP secara lengkap dan sistematis agar pembelajaran berlangsung secara interaktif, inspiratif, menyenangkan, menantang, memotivasi peserta didik untuk berpartisipasi aktif, serta memberikan ruang yang cukup bagi prakarsa, kreativitas, dan kemandirian sesuai dengan bakat, minat dan perkembangan fisik serta psikologis peserta didik. Selain itu idealnya RPP kurikulum 2013 yang dirancang oleh guru, dalam proses pembelajarannya tidak hanya merancang proses pembelajaran yang menuntut siswa menguasai dan mahir pada aspek pengetahuan saja, melainkan juga berkembang dari sisi sikap dan keterampilan.

Pada

kenyataannya berdasarkan hasil observasi dan supervisi yang dilakukan oleh peneliti selaku kepala sekolah SMP Negeri 8 kota Tebingtinggi kemampuan guru-guru dalam menyususn RPP menggunakan kurikulum 2013 masih sangat rendah. Guru-guru terutama guru kelas VII semester I tahun 2016/207 masih mengalami kendala dan merasa bingung dalam membuat RPP menggunakan kurikulum 2013. Dari sebanyak 30 guru yang mengajar di kelas VII, sebanyak 19 guru (63\%) yang masih tidak paham dalam membuat RPP menggunakan kurikulum 2013. Sebanyak 5 guru (16\%) yang sedikit paham tentang penyusunan RPP kurikulum 2013 sementara hanya 6 guru $(21 \%)$ yang sudah paham menyusun RPP dengan menggunakan kurikulum 2013. Sebagian besar RPP yang disusun dan dirancang oleh guru-guru di SMP Negeri 8 kota Tebing Tinggi masih merupakan RPP yang menggunakan kurikulum tingkat satuan pendidikan (KTSP).

Gambaran kemampuan guruguru kelas VII SMP Negeri 8 kota Tebing Tinggi semester I Tahun pembelajaran 2016/2017 dalam menyusun RPP menggunakan kurikulum 2013.

Tabel kemampuan guru-guru kelas VII semester I dalam menyusun Rencana Pelaksanaan Pembelajaran (RPP) menggunakan kurikulum 2013

\begin{tabular}{|c|c|c|c|c|c|}
\hline \multirow{2}{*}{ No } & \multirow{2}{*}{$\begin{array}{c}\text { Jumlah } \\
\text { Guru }\end{array}$} & \multirow{2}{*}{$\%$} & \multicolumn{3}{|c|}{ Menyusun RPP K 13 } \\
\cline { 4 - 6 } & & $\begin{array}{c}\text { Tidak } \\
\text { Paham }\end{array}$ & $\begin{array}{c}\text { Sedikit } \\
\text { Paham }\end{array}$ & Paham \\
\hline 1 & 19 & $63 \%$ & $\mathrm{~V}$ & & \\
\hline 2 & 5 & $16 \%$ & & $\mathrm{~V}$ & \\
\hline 3 & 6 & $21 \%$ & & & $\mathrm{~V}$ \\
\hline
\end{tabular}

Dari tabel di atas, terlihat kemampuan guru-guru SMP Negeri 8 kota Tebingtinggi yang masih sangat rendah dalam menyusun RPP menggunakan kurikulum 2013. Keadaan yang demikian ini tidak bisa dibiarkan dan harus segera dicari solusinya agar proses pembelajaran yang direncanakan oleh guru-guru sesuai dengan kurikulum yang sedang dipakai yaitu kurikulum 2013. 
Melihat keadaan demikian, peneliti sebagai kepala sekolah merasa tertantang dan terpanggil berusaha untuk memberi bimbingan, arahan serta pendampingan pada guru-guru kelas VII dalam menyusun RPP kurikulum 2013 secara lengkap sesuai dengan tuntutan pada standar proses dan standar penilaian yang merupakan bagian dari standar nasional pendidikan yang terdapat pada kurikulum 2013. Hal itu juga sesuai dengan Tupoksi peneliti sebagai kepala sekolah SMP Negeri 8 kota Tebing Tinggi yang berkeinginan agar seluruh guru yang berada di tempat peneliti bertugas memiliki kemampuan professional sebagai seorang pendidik.

Berdasarkan latar belakang di atas, maka masalah-masalah yang muncul dapat diidentifikasikan sebagai berikut.

a. Sebagian besar guru belum paham dalam menyusun rencana pelaksanaan pembelajaran (RPP) sesuai dengan komponen dan langkah langkah yang dituntut pada kurikulum 2013.

b. Sebagian besar guru yang mendapatkan pelatihan kurikulum 2013 merasa pelatihan yang mereka dapatkan belum secara maksimal dan masih membingungkan terutama dalam penyusunan RPP yang diharapkan dalam kurikulum 2013.

c. Rencana pelaksana pembelajaran (RPP) yang dibuat guru masih menggunakan kurikulum tingkat satuan pendidikan (KTSP).
Pendampingan adalah suatu aktivitas/ kegiatan untuk mengetahui, mendengar dan membantu guru dalam mengatasi permasalahan yang dijumpai dalam upaya untuk melaksanakan kegiatan belajar mengajar yang lebih efektif sehingga dapat mencapai tujuan yang telah di tetapkan (Elvi Mailani: 2014). Agar permasalahan yang diteliti tidak terlalu luas, maka penelitian ini dibatasi pada peningkatan kemampuan guru guru dalam menyusun rencana pelaksanaan pembelajaran (RPP) sesuai dengan tuntutan kurikulum 2013 melalui kegiatan pendampingan.

Berdasarkan latar belakang, identifikasi, dan pembatasan masalah di atas, maka rumusan masalah pada penelitian ini adalah.”Apakah melalui kegiatan pendampingan dapat meningkatkan kemampuan guru dalam menyusun rencana pelaksanaan pembelajaran (RPP) sesuai dengan tuntutan kurikulum 2013?"

(PTK) Peni bertujuan untuk meningkatkan kemampuan guru dalam menyusun rencana pelaksanaan pembelajaran sesuai dengan tuntutan kurikulum 2013 melalui kegiatan pendampingan di SMP Negeri 8 kota Tebingtinggi tahun pembelajaran 2016/2017.

\section{METODE PENELITIAN}

Yang menjadi subjek pada penelitian tindakan kelas ini adalah guru guru kelas VII SMP Negeri 8 kota Tebingtinggi yang berjumlah 30 
orang, 11 laki laki dan 19 perempuan. Lokasi penelitian ini di SMP Negeri 8 yang beralamat di jalan Yossudarso kecamatan rambutan, kota Tebingtinggi. Sekolah ini merupakan sekolah dimana peneliti bertugas sebagai kepala sekolah dan berdasarkan observasi yang dilakukan peneliti masih banyak gurunya yang kurang memahami bagaimana membuat RPP sesuai denga tuntutan kurikulum 2013.

Penelitian tindakan kelas ini dilaksanakan pada semester satu tahun 2016 selama kurang lebih enam bulan mulai Juli sampai dengan Desember 2016.

Tabel Jadwal pelaksanaan penelitian seperti pada tabel berikut.

\begin{tabular}{|c|l|l|}
\hline No & \multicolumn{1}{|c|}{ Kegiatan } & \multicolumn{1}{c|}{ Waktu } \\
\hline 1. & $\begin{array}{l}\text { Membuat } \\
\text { proposal }\end{array}$ & 20 s.d. 26 Juli 2016 \\
\hline 2. & $\begin{array}{l}\text { Merevisi } \\
\text { proposal }\end{array}$ & $\begin{array}{l}\text { 9 s.d. 13 Agustus } \\
\text { 2016 }\end{array}$ \\
\hline 3. & $\begin{array}{l}\text { Melaksanakan } \\
\text { PTK }\end{array}$ & $\begin{array}{l}\text { 23 Agustus s.d 20 } \\
\text { Sept 2016 }\end{array}$ \\
\hline 4. & $\begin{array}{l}\text { Membuat } \\
\text { laporan PTK }\end{array}$ & $\begin{array}{l}\text { 24 September s.d. 8 } \\
\text { Oktober 2016 }\end{array}$ \\
\hline 5. & $\begin{array}{l}\text { Mempresentasik } \\
\text { an hasil PTK }\end{array}$ & \begin{tabular}{l} 
18-19 Oktober 2016 \\
\hline
\end{tabular} \\
\hline
\end{tabular}

Penelitian ini berbentuk penelitian tindakan kelas (PTK), yaitu sebuah penelitian yang merupakan kerjasama antara peneliti dan guru, dalam meningkatkan kemampuan guru agar menjadi lebih baik dalam menyusun rencana pelaksanaan pembelajaran sesuai dengan kurikulum 2013.

Metode yang digunakan dalam penelitian ini adalah metode deskriptif, dengan menggunakan teknik persentase untuk melihat peningkatan yang terjadi dari siklus ke siklus. "Metode deskriptif dapat diartikan sebagai prosedur pemecahan masalah yang diselidiki dengan menggambarkan/melukiskan keadaan subjek/objek penelitian (seseorang, lembaga, masyarakat, dan lain-lain) pada saat sekarang berdasarkan fakta-fakta yang tampak atau sebagaimana adanya (Nawawi, 1985:63). Dengan metode ini peneliti berupaya menjelaskan data yang peneliti kumpulkan melalui komunikasi langsung atau wawancara, observasi/pengamatan, dan diskusi yang berupa persentase atau angka-angka.

Penelitian tindakan sekolah (PTK) ini menggunakan model penelitian Suharsimi Arikunto. Penelitian ini terdiri dari 2 siklus dimana dalam setiap siklusnya terdiri dari kegiatan: perencanaan, pelaksanaan, observasi dan refleksi. Prosedur penelitian adalah suatu rangkaian tahap-tahap penelitian dari awal sampai akhir. Penelitian ini merupakan proses pengkajian sistem berdaur sebagaimana kerangka berpikir yang dikembangkan oleh Suharsimi Arikunto dkk. Prosedur ini mencakup tahap-tahap: (1) perencanaan, (2) pelaksanaan, (3) pengamatan, dan (4) refleksi. Keempat kegiatan tersebut saling terkait dan secara urut membentuk sebuah siklus. Penelitian Tindakan Sekolah merupakan penelitian 
Raimunda Simanjuntak : Pendekatan Kemampuan Guru ...

yang bersiklus, artinya penelitian dilakukan secara berulang dan berkelanjutan sampai tujuan penelitian dapat tercapai."

Teknik pengumpulan data dalam penelitian ini adalah wawancara, observasi, dan diskusi. a. Wawancara dipergunakan untuk mendapatkan data atau informasi tentang pemahaman guru terhadap RPP dengan menggunakan kurikulum 2013.

b. Observasi dipergunakan untuk mengumpulkan data dan mengetahui kompetensi guru dalam menyusun RPP kurikulum 2013

c. Diskusi dilakukan antara peneliti dengan guru.

Alat pengumpulan data dalam PTK ini sebagai berikut.

a. Wawancara menggunakan panduan wawancara untuk mengetahui kemampuan awal yang dimiliki guru tentang RPP menggunakan kurikulum 2013

b. Observasi menggunakan lembar observasi untuk mengetahui komponen RPP menggunakan kurikulum 2013 yang telah dibuat dan yang belum dibuat oleh guru

c. Diskusi dilakukan dengan maksud untuk sharing pendapat antara peneliti dengan guru.

Peneliti menentukan indikator keberhasilan penelitian ini apabila 78 $\%$ guru mampu dengan kategori baik menyusun RPP menggunakan kurikulum 2013 sesuai dengan komponen-komponen pada RPP kurikulum 2013.

\section{HASIL PENELITIAN DAN PEMBAHASAN}

Dari hasil observasi dan wawancara terhadap tiga puluh (30) orang guru kelas VII SMP Negeri 8 kota Tebingtinggi semester I tahun pembelajaran 2016/2017, peneliti memperoleh informasi bahwa sebagian besar guru (63\%) tidak paham dalam menyusunan RPP kurikulum 2013, sebanyak 5 guru (15\%) sedikit paham, sedangkan hanya 6 guru (21\%) yang bisa dikatakan paham dan mampu menyusun RPP menggunakan kurikulum 2013. Dalam menyusun dan mempersiapkan RPP umumnya guru mengadopsi dan mengadaptasi RPP dari guru lain. RPP yang diadopsi guru pada umumnya pun masih menggunakan kurikulum tingkat satuan pendidikan (KTSP). Melihat kondisi yang demikian itu, peneliti melakukan kegiatan penelitian dengan tujuan untuk meningkatkan kemampuan dan pemahaman guru dalam menyusun RPP menggunakan kurikulum 2013. Rencana Pelaksanaan Pembelajaran yang dibuat mengacu kepada penerapan kurikulum 2013.

Siklus pertama terdiri dari empat tahap yakni: (1) perencanaan, (2) pelaksanaan, (3) observasi, dan (4) refleksi.

Kegiatan pendampingan
dimulai dari kegiatan pra
pendampingan dimana guru-guru
kelas VII seluruhnya dikumpulkan


dan dilakukan curah pendapat untuk mengetahui sejauh mana pemahaman guru-guru kelas VII SMP negeri 8 kota Tebingtinggi terhadap penyusunan RPP dengan menggunakan kurikulum 2013. Berdasarkan hasil curah pendapat yang dilaksanakan saat pra pendampingan diidentifikasi berbagai kendala yang dirasakan guru-guru dalam menyusun RPP menggunakan kurikulum 2013.

Langkah selanjutnya peneliti melakukan kegiatan pendampingan bagi guru-guru dalam penyusunan RPP menggunakan kurikulum 2013. Kegiatan pendampingan dilakukan mulai dari memberikan penjelasan kepada guru-guru tentang komponen dan perbedaan mendasar dari kurikulum tingkat satuan pendidikan (KTSP) dengan kurikulum 2013. Selanjutnya guru-guru dalam kelompok mata pelajaran diberikan tugas untuk menyusun RPP kurikulum 2013 berdasarkan penjelasan yang diberikan oleh peneliti. Dalam kelompok mata pelajaran sesuai dengan jadwal yang telah ditentukan, peneliti melakukan kegiatan pendampingan dengan cara bersama dengan guru-guru menyusun RPP kurikulum 2013 yang akan dipergunakan dalam proses pembelajaran di dalam kelas.

Kegiatan selanjutnya peneliti mendampingi guru dalam melaksanakan proses pembelajaran dengan menggunakan RPP kurikulum 2013 yang telah dirancang bersama pada kegiatan sebelumnya. Peneliti bersama seorang guru mengamati proses pembelajaran yang dilakukan oleh guru, mencatat seluruh kekuatan dan kelemahan yang dilakukan oleh guru yang akan menjadi masukan saat kegiatan pasca pendampingan. Kegiatan pasca pendampingan dilakukan setelah proses pendampingan baik pendampingan dalam menyusun perencanaan maupun pendampingan saat pembelajaran selesai dilakukan. Pada kegiatan pasca pendampingan peneliti dan guru-guru melakukan refleksi terhadap RPP kurikulum 2013 yang telah disusun seiring dengan proses pembelajaran yang telah dilakukan. Saat kegiatan pasca pendampingan ini guru yang di damping peneliti diharapkan mampu memperbaiki RPP kurikulum 2013 yang telah disusun sesuai dengan pengalaman yang dirasakan saat proses pembelajaran berlangsung dan berdasarkan masukan yang diberikan oleh observer.

Observasi dan penilaian dilaksanakan saat guru telah selesai membuat RPP dengan menggunakan kurikulum 2013 dan saat guru mengajar dengan menggunakan RPP kurikulum 2013 yang disusun guru saat kegiatan pendampingan. Observasi dilakukan oleh peneliti bersama seorang guru yang berperan sebagai observer. Hasil observasi dijadikan sebagai bahan untuk perbaikan RPP kurikulum 2013 yang dirancang oleh guru beserta masukan yang dirasakan oleh guru saat melakukan proses belajar mengajar.

Adapun hasil penilaian terhadap RPP kurikulum 2013 yang 
dibuat guru dan hasil observasi pembelajaran yang dilakukan peneliti bersama seorang guru yang berperan sebagai observer, menunjukkan kemampuan guru-guru semester VII SMP Negeri 8 kota Tebingtinggi tahun pembelajaran 2016/2017 masih tergolong rendah. Dari tiga puluh orang guru yang mengajar di kelas VII, hanya 18 guru ( 60\%) yang telah paham menyusun RPP kurikulum 2013 dan mampu mengimplementasekannya di dalam kelas, sebanyak 5 guru (16\%) mulai paham dan selebihnya sebanyak 7 orang guru (24\%) belum paham dalam menyusun RPP menggunakan kurikulum 2013.

Gambaran kemampuan guru kelas VII semester I SMP Negeri 8 kota Tebing Tinggi dalam menyusun RPP menggunakan kurikulum 2013 siklus I dapat dilihat pada tabel di bawah ini.

Tabel Pemahaman guru dalam menyusun RPP kurikulum 2013 siklus I

\begin{tabular}{|c|c|c|c|c|c|}
\hline \multirow{2}{*}{ No } & \multirow{2}{*}{$\begin{array}{c}\text { Jumlah } \\
\text { Guru }\end{array}$} & \multirow{\%}{*}{} & \multicolumn{3}{|c|}{ Menyusun RPP K 13 } \\
\cline { 4 - 6 } & & $\begin{array}{c}\text { Tidak } \\
\text { Paham }\end{array}$ & $\begin{array}{c}\text { Sedikit } \\
\text { Paham }\end{array}$ & Paham \\
\hline 1 & 18 & $60 \%$ & & & V \\
\hline 2 & 5 & $16 \%$ & & V & \\
\hline 3 & 7 & $24 \%$ & $\mathrm{~V}$ & & \\
\hline
\end{tabular}

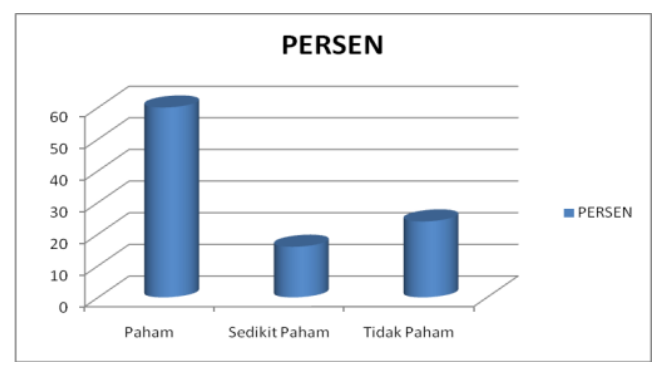

Gambar Pemahaman guru dalam menyusun RPP kurikulum 2013 siklus I
Dari tabel dan gambar di atas terlihat kemampuan guru-guru kelas VII SMP Negeri 8 kota Tebing Tinggi masih rendah dan belum memenuhi indikator keberhasilan yang ditentukan pada penelitian ini. Rendahnya kemampuan guru dalam menyusun RPP menggunakan kurikulum 2013 terlihat pada aspek pendekatan pembelajaran serta penilaian autentik yang dituntut menjadi perbedaan yang mendasar antara kurikulum tingkat satuan pendidikan (KTSP) dengan kurikulum 2013.

Setelah dilaksanakan tindakan pada siklus I dan berdasarkan RPP kurikulum 2013 yang dirancang oleh guru, dan hasil observasi yang dilakukan saat proses belajar mengajar berlangsung maka beberapa hal yang menjadi catatan saat pelaksanaan tindakan siklus I adalah: ( a) masih ada sebagian guru yang kegiatan pembelajaran masih belum menggunakan pendekatan saintifik/ model-model pembelajaran, (b) masih ada guru yang merumuskan penilaian belum menggunakan penilaian autentik, (c) sebagian guru masih mengajar tanpa menggunakan media pembelajaran.

Dari hasil penilaian dan observasi yang dilakukan pada siklus I terlihat kemampuan guru-guru kelas VII SMP Negeri 8 kota Tebing Tinggi dalam menyusun RPP dengan menggunakan kurikulum 2013 belum memenuhi standar indikator keberhasilan penelitian yang telah ditentukan sebelumnya. Oleh karena 
itu penelitian ini harus dilanjutkan pada siklus II.

Pada siklus II peneliti melakukan kegiatan pendampingan sama hal nya dengan pendampinga yang dilakukan pada siklus I. Pada kegiatan pendampingan akan dilaksanakan mulai dari kegiatan pra pendampingan, pendampingan serta pasca pendampingan. Perbedaan yang mendasar pada kegiatan pendampingan yang dilakukan antara siklus I dan siklus II adalah jika pada siklus I dilaksanakan pendampingan secara kelompok mata pelajaran, maka pada siklus II dilaksanakan pendampingan secara individu. Kepada tiga puluh orang guru- guru yang terdapat di SMP Negeri 8 kota Tebing Tinggi.

\begin{tabular}{cr}
\multicolumn{2}{c}{ Pendampingan secara } \\
individu dilakukan untuk
\end{tabular}
memberikan pemahaman yang lebih kepada setiap guru tentang RPP kurikulum 2013. Pendampingan secara individu diharapkan memberikan kebebasan dan keberanian bertanya guru dalam upaya meningkatkan pemahaman mereka terhadap komponenkomponen RPP yang menggunakan kurikulum 2013.

Kegiatan observasi siklus II sama hal nya dilakukan seperti pada siklus I. Observasi dilaksanakan saat guru mengajar dengan menggunakan RPP kurikulum 2013 yang disusun guru saat kegiatan pendampingan. Observasi dilakukan oleh peneliti bersama seorang guru yang berperan sebagai observer. Hail observasi dijadikan sebagai bahan untuk perbaikan RPP kurikulum 2013 yang dirancang oleh guru beserta masukan yang dirasakan oleh guru saat melakukan proses belajar mengajar.

Setelah siklus II selesai dilaksanakan peneliti melakukan penilaian terhadap RPP kurikulum 2013 yang dibuat guru-guru serta berdasarkan hasil observasi yang dilakukan saat proses pembelajaran berlangsung. Adapun hasil penilaian terhadap RPP kurikulum 2013 yang dibuat guru dan hasil observasi pembelajaran yang dilakukan peneliti bersama seorang guru yang berperan sebagai observer setelah siklus II selesai dilaksanakan, menunjukkan peningkatan kemampuan dan pemahaman guru-guru semester VII SMP Negeri 8 kota Tebing Tinggi tahun pembelajaran 2016/2017 dalam menyusun RPP kurikulum 2013. Dari tiga puluh orang guru yang mengajar di kelas VII, hanya 26 guru $(87 \%)$ yang telah paham menyusun RPP kurikulum 2013 dan mampu mengimplementasekannya di dalam kelas, dan hanya 4 orang guru (13\%) belum paham dalam menyusun RPP menggunakan kurikulum 2013. Gambaran kemampuan guru kelas VII semester I SMP Negeri 8 kota Tebing Tinggi dalam menyusun RPP menggunakan kurikulum 2013 siklus II dapat dilihat pada tabel di bawah ini.

Tabel Pemahaman guru dalam menyusun RPP kurikulum 2013 siklus II

\begin{tabular}{|c|c|c|c|c|c|}
\hline \multirow{2}{*}{ No } & \multirow{2}{*}{$\begin{array}{c}\text { Jumlah } \\
\text { Guru }\end{array}$} & \multirow{2}{*}{$\%$} & \multicolumn{3}{|c|}{ Menyusun RPP K 13 } \\
\cline { 4 - 6 } & & $\begin{array}{c}\text { Tidak } \\
\text { Paham }\end{array}$ & $\begin{array}{c}\text { Sedikit } \\
\text { Paham }\end{array}$ & Paham \\
\hline 1 & 26 & $87 \%$ & & & V \\
\hline 2 & 4 & $13 \%$ & $\mathrm{~V}$ & & \\
\hline
\end{tabular}




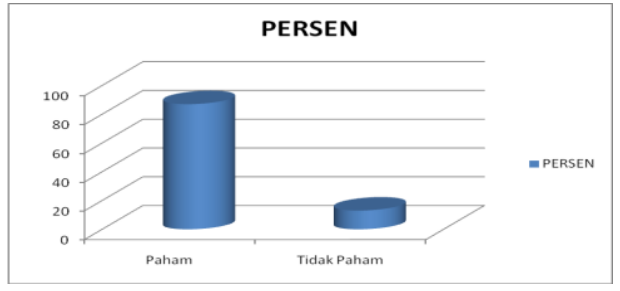

Gambar Pemahaman guru dalam menyusun RPP kurikulum 2013 siklus II

Dari tabel dan gambar di atas terlihat kemampuan guru-guru kelas VII SMP Negeri 8 kota Tebing Tinggi sudah baik dan sudah mampu untuk menyusun serta mengimplementasekannya yaitu RPP kurikulum yang dibuat guru dalam proses pembelajaran di dalam kelas. Dari tiga puluh orang guru kelas VII SMP negeri 8 kota Tebingtinggi, sebanyak 26 guru (87\%) telah mampu menyusun RPP menggunakan kurikulum 2013. Hanya 4 orang guru (13\%) yang masih belum mampu, namun kalau terus didampingi kemampuan emapat orang guru tersebut akan meningkat.

$$
\text { Setelah dilaksanakan }
$$

tindakan pada siklus II dan berdasarkan RPP kurikulum 2013 yang dirancang oleh guru setelah proses pendampingan pada siklus II dilaksanakan, dan hasil observasi yang dilakukan saat proses belajar mengajar berlangsung terlihat kemampuan guru-guru kelas VII SMP Negeri 8 kota Tebing Tinggi dalam merancang RPP kurikulum 2013 semakin meningkat. Hal ini terjadi karena guru-guru telah memahami komponen-komponen yang harus terdapat pada RPP kurikulum 2013 setelah mendapatkan pendampingan dari peneliti.

Berdasarkan hasil penelitian yang telah dilakukan pada siklus II, terlihat kemampuan guru kelas VII SMP negeri 8 kota Tebing Tinggi, telah memenuhi indikator keberhasilan penelitian yang telah ditetapkan dalam menyusun RPP menggunakan kurikulum 2013, sehingga penelitian ini tidak perlu dilanjutkan lagi pada siklus berikutnya.

\section{Pembahasan}

Hasil penelitian tindakan kelas yang dilakukan menunjukkan peningkatan kemampuan guru-guru kelas VII SMP Negeri 8 kota Tebingtinggi dalam menyusun RPP menggunakan kurikulum 2013 setelah dilakukan kegiatan pendampingan yang dilakukan oleh peneliti. Hal ini dapat dilihat dari hasil penilaian terhadap RPP kurikulum 2013 yang dibuat oleh guru dan hasil observasi yang dilakukan saat guru mengimplementasekan RPP kurikulum 2013 di dalam proses belajar mengajar di dalam kelas.

Jika sebelum kegiatan pendampingan dilakukan kemampuan guru-guru dalam menyusun RPP kurikulum 2013 masih sangat rendah, ini terlihat dari hasil observasi dan wawancara yang dilakukan terhadap 30 orang guru yang mengajar di kelas VII semester I tahun pembelajaran 2016/2017. Hasil wawancara dan observasi ini menunjukkan dari 30 orang guru 
yang mengajar di kelas VII, sebanyak 19 guru (63\%) yang masih tidak paham dalam membuat RPP menggunakan kurikulum 2013. Sebanyak 5 guru (16\%) yang sedikit paham tentang penyusunan RPP kurikulum 2013 sementara hanya 6 guru $(21 \%)$ yang sudah paham menyusun RPP dengan menggunakan kurikulum 2013.

Setelah dilaksanakan pendampingan pada siklus I dalam penyusunan RPP menggunakan kurikulum 2013, terjadi peningkatan kemampuan guru dalam menyusun RPP menggunakan kurikulum 2013. Hal ini dapat terlihat dari Dari tiga puluh orang guru yang mengajar di kelas VII, sudah 18 guru (60\%) yang telah paham menyusun RPP kurikulum 2013 dan mampu mengimplementasekannya di dalam kelas terjadi peningkatan sebanyak 12 guru (40\%) jika dibandingkan sebelum kegiatan pendampingan dilakukan. Sementara guru yang belum paham dalam menyusun RPP menggunakan kurikulum 2013 berkurang dari 19 guru ( $63 \%$ ) menjadi hanya tinggal 4 guru ( $13 \%$ ). Terjadi penurunan sebanyak 50\% jika dibandingkan dengan sebelum siklus I dilaksanakan.

Berdasarkan hasil perolehan yang terdapat pada siklus I, terlihat pencapaian kemampuan guru dalam menyusun RPP menggunakan kurikulum 2013 belum sesuai dengan indicator keberhasilan penelitian, maka dilaksanakanlah penelitian pada siklus II. Setelah siklus II dilaksanakan, terlihat kemampuan guru meningkat dalam menyusun RPP menggunakan kurikulum 2013. Dari tiga puluh orang guru kelas VII SMP negeri 8 kota Tebingtinggi, sebanyak 26 guru (87\%) telah mampu menyusun RPP menggunakan kurikulum 2013 terjadi peningkatan sebanyak $27 \%$ (8 orang guru), dan hanya 4 orang guru (13\%) yang masih belum mampu menyusun RPP menggunakan kurikulum 2013 terjadi penurunan $6 \%$ (2 orang guru) jika dibandingkan dengan hasil yang diperoleh pada siklus I. Tabel peningkatan kemampuan guru kelas VII smester I tahun pembelajaran 2016/2017 SMP Negeri 8 kota Tebing Tinggi dapat dilihat pada tabel berikut:

Tabel Peningkatan Kemampuan Guru SMP Negeri 8 dalam Menyusun RPP Kurikulum 2013

\begin{tabular}{|c|c|c|c|c|c|c|c|}
\hline \multirow{2}{*}{ No } & \multirow{2}{*}{ Kegiatan } & \multicolumn{6}{|c|}{ Keterangan } \\
\cline { 3 - 8 } & & \multicolumn{2}{|c|}{ Mampu } & \multicolumn{2}{|c|}{$\begin{array}{c}\text { Sedikit } \\
\text { Mampu }\end{array}$} & \multicolumn{2}{|c|}{$\begin{array}{c}\text { Tidak } \\
\text { Mampu }\end{array}$} \\
\hline 1 & $\begin{array}{c}\text { Pra } \\
\text { Siklus }\end{array}$ & 6 & $21 \%$ & 5 & $16 \%$ & 19 & $63 \%$ \\
\hline 2 & Siklus I & 18 & $60 \%$ & 5 & $16 \%$ & 7 & $24 \%$ \\
\hline 3 & Siklus II & 26 & $87 \%$ & 0 & $0 \%$ & 4 & $13 \%$ \\
\hline & & & & & & & \\
\hline
\end{tabular}

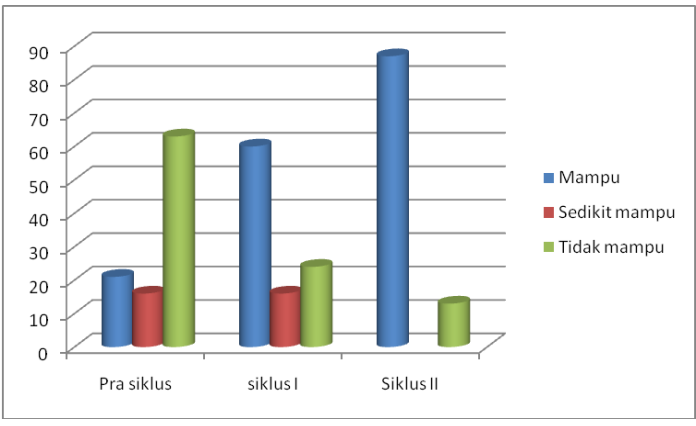

Gambar Peningkatan Kemampuan Guru SMP Negeri 8 dalam Menyusun RPP Kurikulum 2013 


\section{SIMPULAN}

Berdasarkan hasil penelitian tindakan kelas (PTK) dapat disimpulkan sebagai berikut.

a. Kegiatan pendampingan dapat meningkatkan kemampuan guruguru kelas VII SMP Negeri 8 kota Tebingtinggi dalam menyusun RPP menggunakan kurikulum 2013 tahun pembelajaran 2016/2017.

b. Kegiatan pendampingan dapat meningkatkan kemampuan guru dalam menyusun RPP menggunakan kurikulum 2013, hal itu dapat dibuktikan dari hasil penilaian dan observasi /pengamatan yang memperlihatkan bahwa terjadi peningkatan kompetensi guru dalam menyusun RPP menggunakan kurikulum 2013, jika sebelum pendampingan dilakukan jumlah guru yang mampu membuat RPP dengan menggunakan kurikulu 2013 hanya sebanyak 6 orang guru (21\%) maka setelah siklus II dilaksanakan jumlah guru yang mampu membuat RPP kurikulum 2013 meningkat menjadi 26 orang guru (87\%). Terjadi peningkatan kemampuan guru sebanyak 20 orang $(66 \%)$

\section{DAFTAR RUJUKAN}

Depdiknas. 2007. Permendiknas RI No. 41 Tahun 2007 a tentang Standar Proses. Jakarta: Depdiknas.
Depdiknas. 2007. Permendiknas RI No. 12 Tahun $2007 b$ tentang Standar Pengawas Sekolah/Madrasah. Jakarata: Depdiknas.

Depdiknas. 2008. Alat Penilaian Kemampuan Guru. Jakarta: Depdiknas.

Kemendiknas. 2010. Penelitian Tindakan Sekolah. Jakarta.

Kumaidi. 2008. Sistem Sertifikasi (http://massofa.wordpress.com diakses 10 Agustus 2009).

Mailani, E. 2014. Upaya Meningkatkan Kompetensi Paedagogik Guru Dalam Menyusun Rencana Pelaksanaan Pembelajaran Melalui Kegiatan Pendampingan (Mentoring). SCHOOL EDUCATION JOURNAL PGSD FIP UNIMED, 1(2).

Sudjana, Nana. 2009. Standar Kompetensi Pengawas Dimensi dan Indikator. Jakarta: Binamitra Publishing. 